\title{
Bibliography
}

\section{Newspapers and Journals}

Andersonstown News

Anglo-Celt

An Phoblacht

An Phoblacht/Republican News

Belfast Bulletin

Bottom Dog

Business and Finance

Church of Ireland Gazette

Clare Champion

Comment

Connacht Tribune

Cork Examiner

Derry Journal

Donegal Democrat

Donegal News

Drogheda Independent

Dublin Review of Books

Dundalk Democrat

Echo and South Leinster Advertiser Evening Herald

Evening Press

Garda Review

Herald and Western Advertiser

Hibernia

Hot Press

In Dublin

International Socialism

Ireland's Own

Irish Independent

Irish People 
Irish Press

Irish Reporter

Irish Socialist

Irish Times

The Kerryman

Kilkenny People

Leinster Leader

Leitrim Observer

Liberty

Limerick Leader

Limerick Socialist

London Review of Books

Longford Leader

Magill

Mayo News

Meath Chronicle

Munster Express

Nationalist (Clonmel)

Nationalist and Leinster Times

Nenagh Guardian

New Ross Standard

New Statesman

Northern Standard

Nusight

Pobal

Profile

Rebel

Roscommon Herald

Sligo Champion

Socialist Republic

Southern Star

Starry Plough

Sunday Independent

Sunday Press

Sunday Tribune

Sunday World

The Word

The Worker

This Week

Time Out

Tipperary Star

Trade Union Information

Tuam Herald

TUCCAR Newsletter

Unfree Citizen

United Irishman

Vanguard

Village

Western People

Westmeath Examiner

Westmeath-Offaly Independent

Wexford People 
Wicklow People

Woman's Way

Workers' Weekly

\section{Books}

Adair, L. and Murphy, C., Untold Stories: Protestants in the Republic of Ireland 1922-2002 (Dublin, 2002).

Ahern, B., The Autobiography (London, 2009).

Allen, G., The Garda Síochána: Policing Independent Ireland 1922-82 (Dublin, 1999).

Anderson, B., Joe Cahill: A Life in the IRA (Dublin, 2002).

Arnold, B., What Kind of Country; Modern Irish Politics 1968-1983 (London, 1984).

Barrett, J.J., Martin Ferris: Man of Kerry (Dingle, 2005).

Bean, K., The New Politics of Sinn Féin (Liverpool, 2007).

Boland, K., Up Dev! (Dublin, 1977).

— "We Won't Stand (Idly) By" (Dublin, 1972).

Boran, P., The Invisible Prison: Scenes from an Irish Childhood (Dublin, 2009).

Bourke, R., 'Languages of conflict and the Northern Ireland Troubles', The Journal of Modern History 83 (September, 2011).

Bowen, K., Protestants in a Catholic State: Ireland's Privileged Minority (Dublin, 1983).

Bowman, J., Window and Mirror: RTÉ Television: 1961-2011 (Cork, 2011).

Bowyer Bell, J., The Secret Army: A History of the IRA 1915-1970 (London, 1970).

- The Secret Army: The IRA (Dublin, 1979).

- In Dubious Battle: The Dublin Bombings, 1972-74 (Dublin, 1996).

Brady, C., The Guarding of Ireland: The Garda Siochána and the Irish State 1960-2014 (Dublin, 2014).

Bray, P., Inside Man: Life as an Irish Prison Officer (Dublin, 2008).

Brewer, J.D., Lockhart, B. and Rodgers, P., 'Crime in Ireland 1945-95' in A.F. Heath, R. Breen and C.T. Whelan (Eds), Ireland North and South: Perspectives from Social Science (Oxford, 1999).

British \& Irish Communist Organisation, Aspects of Nationalism (Belfast, 1971).

- The Economics of Partition (Belfast, 1972).

- The Rise of Papal Power in Ireland (Belfast, 1979).

- Stalin and the Irish Working Class (Belfast, 1979).

Browne, N.C., Against the Tide (Dublin, 1986).

Browne, T., Ireland: A Social and Cultural History 1922-2002 (London, 2004).

Browne, V. and Farrell, M., The Magill Book of Irish Politics (Dublin, 1981).

Burgess, T.P. and Mulvenna, G. (Eds) The Contested Identities of Ulster Protestants (London, 2015).

Bury, R., Buried Lives: The Protestants of Southern Ireland (Dublin, 2017).

Busteed, M.A., Voting Behaviour in the Republic of Ireland: A Geographical Persepctive (Oxford, 1990).

Busteed, M.A. and Mason, H., 'The 1973 General Election in the Republic of Ireland', Irish Geography 7 (1974).

Busteed, M.A., Neal, F. and Tonge, J. (Eds) Irish Protestant Identities (Manchester, 2008).

Byrne, G., The Time of My Life: An Autobiography (Dublin, 1989).

- To Whom it Concerns (Dublin, 1972).

Cadwallader, A., Lethal Allies: British Collusion in Ireland (Cork, 2013).

Callan, C. and Desmond, B., Irish Labour Lives: A Biographical Dictionary of Irish Labour Party Deputies, Senators, MPs and MEPs (Dublin, 2010).

Callanan, F., The Literary and Historical Society, 1955-2005 (Dublin, 2005). 
Cathcart, R. and Muldoon, M., 'The Mass Media in Twentieth-century Ireland' in New History of Ireland Vol. VII, J. Hill (Ed.) Ireland 1921-1984 (Oxford, 2004).

Chubb, B. 'Society and the Political System' in H. Penniman (Ed.) Ireland at the Polls: The 1977 Dáil Elections (Washington DC, 1978) pp. 1-20.

Clann na hÉireann, Spies in Ireland (London, 1974).

Cody, S., O'Dowd, J. and Rigney, P., The Parliament of Labour: 100 Years of the Dublin Council of Trade Unions (Dublin, 1986).

Connery, D., The Irish (London, 1968).

Connolly, L. and O'Toole, T., Documenting Irish Feminisms: The Second Wave (Dublin, 2005).

Conlon, E. (Ed.) Later On: The Monaghan Bombing Memorial Anthology (Dingle, 2004).

Convery, D. (Ed.) 'Locked Out': A Century of Irish Working Class Life (Dublin, 2013).

Conway, K., Southside Provisional: From Freedom Fighter to Four Courts (Dublin, 2014).

Conway, V., Policing Twentieth-Century Ireland: A History of An Garda Síochána (London, 2014).

Coogan, T.P., Ireland Since the Rising (London, 1966).

- The IRA (London, 1970).

- The Irish: A Personal View (London, 1975).

- A Memoir (London, 2008).

Corcoran, M.P. and O'Brien, M. (Eds) Political Censorship and the Democratic State: The Irish Broadcasting Ban (Dublin, 2005).

Courtney, J., It Was Murder! (Dublin, 1996).

Craig, A., Crisis of Confidence: Anglo-Irish Relations in the Early Troubles, 1966-1974 (Dublin, 2010).

Crawford, H., Outside the Glow: Protestants and Irishness in Independent Ireland (Dublin, 2010).

Cunningham, M., Monaghan: County of Intrigue (Donegal, 1979).

D’Alton, I., "A Vestigal Population"? Perspectives on Southern Irish Protestants in the twentieth century', Éire - Ireland 44 (Fall/Winter 2009).

Daly, C., Violence in Ireland and Christian Conscience (Dublin, 1973).

Daly, M., Sixties Ireland: Reshaping the Economy, State and Society, 1957-1973 (Cambridge, 2016).

Daly, P., O'Brien, R. and Rouse, P., Making the Difference: The Irish Labour Party, 1912-2012 (Cork, 2012).

Davis, E.E. and Sinnott, R., Attitudes In The Republic of Ireland Relevant To The Northern Ireland Problem: Vol 1, Dublin Economic and Social Research Institute Paper No. 97 (September, 1979).

- 'The controversy concerning attitudes to the Northern Ireland problem', Studies 69 (Autumn/Winter 1980).

Delaney, E., Demography, State and Society: Irish Migration to Britain, 1921-1971 (Liverpool, 2000).

- The Irish in Post-War Britain (Oxford, 2007).

de Paor, L., Divided Ulster (London, 1980).

- Unfinished Business: Ireland Today and Tomorrow (London, 1990).

- 'UCD and the Pattern of Revolt' in P. Pettit (Ed.) The Gentle Revolution: Crisis in the Universities (Dublin, 1969) pp. 60-66.

Derwin, D., 'The ITGWU', International Socialism 92 (Oct. 1976) pp. 34-36.

Desmond, B., Finally and in Conclusion (Dublin, 2000).

Devine, F., Understanding Social Justice: Paddy Cardiff and the Discipline of Trade Unionism (Dublin, 2002).

- Organising History: A Centenary of SIPTU, 1909-2009 (Dublin, 2009).

- 'Mattie O’Neill', Saothar 17 (1992). 
Drogheda Community Forum, Dispelling the Myths (Drogheda, 2004).

Duggan, J.P., A History of the Irish Army (Dublin, 1991).

Dunlop, F., Yes Taoiseach: Irish Politics from Behind Closed Doors (Dublin, 2004).

Dunne, D. and Kerrigan, G., Round Up the Usual Suspects: Nicky Kelly and the Cosgrave Coalition (Dublin, 1984).

Dunne, T., Rebellions: Memoir, Memory and 1798 (Dublin, 2004).

Dunne, T. and Geary, L., History and the Public Sphere: Essays in Honour of John A. Murphy (Cork, 2005).

Dunphy, E., The Rocky Road (Dublin, 2013).

Fanning, R., Independent Ireland (Dublin, 1983).

Farrell, B. and Manning, M., 'The Election' in H. Penniman (Ed.) Ireland at the Polls: The Dáil Elections of 1977 (Washington D.C., 1978).

Farset Community, Separated by Partition: An Encounter between Protestants from East Donegal and East Belfast (Belfast, 2000).

Faulkner, P., As I Saw It: Reviewing Over 30 Years of Fianna Fáil \& Irish Politics (Dublin, 2005).

Feeney, T., Seán MacEntee: A Political Life (Dublin, 2008).

Fennell, D., Build the Third Republic (Galway, 1972).

- A New Nationalism for a New Ireland (Monaghan, 1972).

- Nice People and Rednecks: Ireland in the 1980s (Dublin, 1986).

- The Revision of Irish Nationalism (Dublin, 1989).

- About Being Normal: My Life in Abnormal Circumstances (Cork, 2017).

Ferris, M., Prison Struggle: Portlaoise Gaol 1917-1985 (Dublin, 1994).

Ferriter, D., Ambiguous Republic: Ireland in the 1970s (London, 2012).

FitzGerald, G., Towards a New Ireland (London, 1972).

- All in a Life: An Autobiography (London, 1992).

- 'The 1974-75 threat of a British withdrawal from Northern Ireland', Irish Studies in International Affairs 17 (2006).

Fitzpatrick, D., Descendancy: Irish Protestant Histories since 1795 (Cambridge, 2014).

Foley, F., 'North-South relations and the outbreak of the Troubles: the response of the Irish Press', Irish Studies in International Affairs 14 (2003).

Foster, R.F., Luck and the Irish: A Brief History of Change 1970-2000 (London, 2007).

Gallagher, M. (Ed.) Irish Elections, 1948-77: Results and Analysis (Oxford, 2009).

Geraghty, T. and Whitehead, T., The Dublin Fire Brigade (Dublin, 2004).

Gibson, B., The Birmingham Bombs (Chichester, 1976).

Gillfillan, K. (Ed.) Trinity Tales: Trinity College Dublin in the Seventies (Dublin, 2011).

Gogan, L., Larry Gogan's Pop File (Dublin, 1979).

Hachey, T. (Ed.) Turning Points in Twentieth-Century Irish History (Dublin, 2011).

Hanley, B., 'Charlie Bourne, Jack Ford and the Green Fields of France' in J. Horne and E. Madigan (Eds) Towards Commemoration: Ireland in War and Revolution, 1912-1923 (Dublin, 2013).

- 'But then they started all this killing': attitudes to the IRA in the Irish Republic since 1969', Irish Historical Studies 38 (May 2013).

— 'I ran away'? The IRA and 1969: the evolution of a myth', Irish Historical Studies 38 (Nov. 2013).

- 'We mourn our brothers ...' Workers respond to Bloody Sunday and the Northern Ireland conflict, 1968-72', Saothar 42 (2017).

Hanley, B. and Millar, S., The Lost Revolution: The Story of the Official IRA and the Workers Party (Dublin, 2010).

Harte, P., Young Tigers and Mongrel Foxes (Dublin, 2005).

Harvey, B., Cosgrave's Coalition (London, 1978). 
Harvey, B., Kelly, A., McGearty, S. and Murray, S., The Emerald Curtain: The Social Impact of the Irish Border (Monaghan, 2005).

Hennessey, T., Northern Ireland: The Origins of the Troubles (Dublin, 2005).

Higgins, R., Transforming 1916: Meaning, Memory and the Fiftieth Anniversary of the Easter Rising (Cork, 2012).

Holland, J. and McDonald, H., INLA: Deadly Divisions (Dublin, 1994).

Holohan, C., 'Challenges to social order and Irish identity? youth culture in the sixties', Irish Historical Studies 151 (May 2013).

Hopkinson, M., Green against Green: The Irish Civil War (Dublin, 1988).

Horgan, J., Noel Browne: Passionate Outsider (Dublin, 1997).

- Broadcasting and Public Life: RTE News and Current Affairs, 1926-1997 (Dublin, 2004).

— 'Irish television and newspapers, 1962-72: an armed truce?', Éire-Ireland 50, No. 1 and 2 (Spring/Summer 2015).

Howard, P., Hostage: Notorious Irish Kidnappings (Dublin, 2004).

Hussey, B. and Kealy, A. (Ed.) Nothing is Written in Stone: The Notebook of Justin Keating (Dublin, 2017).

Independent Socialist Party, The Independent Socialist Party: An Introduction (Dublin, 1977).

Irish Council for Civil Liberties, The Emergency Powers Act, 1976: A Critique (Dublin, 1977).

Irish Marketing Surveys, Northern Ireland: A Survey of Prevailing Attitudes in the Republic of Ireland (Dublin, 1978).

Irish Republican Socialist Party, Framed Through The Special Criminal Court, The 'Great Train Robbery' Trial (Dublin, 1979).

Ivory, G., 'Fianna Fáil, Northern Ireland and the limits of conciliation, 1969-1973', Irish Political Studies 29 (Jan. 2013).

- 'RTÉ and the Coverage of Northern Ireland on television news bulletins in the early years of the Troubles', Irish Communications Review 13 (2013).

Jordan, N., Michael Collins: Film Diary \& Screenplay (London, 1996).

Kee, R., Ireland: A History (London, 1980).

Kelly, S., 'A Failed Political Entity': Charles Haughey and the Northern Ireland Question, 1945-1992 (Dublin, 2013).

- Fianna Fail, Partition and Northern Ireland, 1926-1971 (Dublin, 2016).

Kennedy, M., 'This Tragic and Most Intractable Problem': the reaction of the Department of External Affairs to the outbreak of the Troubles in Northern Ireland', Irish Studies in International Affairs 12 (2001).

Kenny, B., Tony Heffernan, From Merrion Square to Merrion St (Dublin, 2013).

Kenny, I., Talking to Ourselves: Conversations with Editors of the Irish News Media (Galway, 1994).

Keogh, D., Jack Lynch: A Biography (Dublin, 2008).

Kerrigan, G., Hard Cases: True Stories of Irish Crime (Dublin, 1996).

- Another Country: Growing Up in 1950's Ireland (Dublin, 1998).

— 'The confession of Christy Lynch', Magill, 1 Feb. 1984.

Knatchbull, T., From a Clear Blue Sky: Surviving the Mountbatten Bomb (London, 2010).

Knight, J. and Baxter-Moore, N., Republic of Ireland: The General Elections of 1969 and 1973 (London, 1973).

Lee, J.J., (Ed.) Ireland, 1945-70 (Dublin, 1979).

- Modern Ireland, 1912-1985: Politics and Society (Cambridge, 1989).

Logue, P., Them and Us: A Socialist Response to 'Work is the Key' (Dublin, 1994).

Mac Gréil, M., Prejudice and Tolerance in Ireland: Based on a Survey of Intergroup Attitudes of Dublin Adults and Other Sources (Dublin, 1977).

Mac Mánais, R., The Road From Ardoyne: The Making of a President (Dingle, 2005).

Mac Stiofáin, S., Memoirs of a Revolutionary (London, 1975). 
Madden, A., Fear and Loathing in Dublin (Dublin, 2009).

Madden, G., 'Responses in the west of Ireland to civil rights protest in Northern Ireland, 1968-72', Irish Historical Studies 41 (May, 2017).

Magee, J., 'The teaching of Irish history in Irish schools', The Northern Teacher 10, No. 1 (Winter 1970).

Maguire, C., Roddy Connolly and the Struggle for Socialism in Ireland (Cork, 2008).

- 'Defenders of the State: the Irish Labour Party, coalitionism and revisionism, 1969-77', Irish Studies Review 23 (2015).

Maguire, M., To Take Arms: My Year with the IRA Provisionals (London, 1973).

Maye, B., Fine Gael 1923-1987 (Dublin, 1993).

McBride, I., 'The shadow of the gunman: Irish historians and the IRA', Journal of Contemporary History 46, No. 3 (2011).

McCafferty, N., Nell (London, 2004).

McCann, E., War and an Irish Town (London, 1974).

- Bloody Sunday in Derry: What Really Happened (Dingle, 1992).

McCarthy, C., The Decade of Upheaval: Irish Trade Unions in the Nineteen Sixties (Dublin, 1973).

McCarthy, Conor, Modernisation, Crisis and Culture in Ireland, 1969-1992 (Dublin, 2000).

McCarthy, K., Republican Cobh and the East Cork Volunteers since 1913 (Dublin, 2008).

McCarthy, M., Ireland's 1916 Rising: Explorations of Historial Memory, Commemoration and Heritage in Modern Times (Surrey, 2012).

McCreary, A., Profiles of Hope (Belfast, 1981).

McDaid, S., 'The David Thornley Affair: Republicanism and the Irish Labour Party' in C. Nic Dháibhéid and C. Reid (Eds) From Parnell to Paisley (Dublin, 2010).

McDowell, R.B., Crisis and Decline: The Fate of the Southern Unionists (Dublin, 1997).

- McDowell on McDowell: A Memoir (Dublin, 2008).

McGinley, J. (Ed.) Frank Cluskey: The Conscience of Labour (Dublin, 2015).

McGladdery, G., The Provisional IRA in England: The Bombing Campaign, 1973-1997 (Dublin, 2006).

McGrain, D., 'From Peking to Aubane', www.Indymedia.ie/article/80451.

McGuire, C., 'Defenders of the State: The Irish Labour Party, coalitionism and revisionism, 1969-77', Irish Studies Review 23 (2015) pp. 1-20.

McKay, S., Bear in Mind these Dead (London, 2008).

McKearney, T., The Provisional IRA: From Insurrection to Parliament (London, 2011).

McKeown, K., 'A critical examination of some findings of the Davis and Sinnott Report', Studies 69 (Summer, 1980).

McKittrick, D., Kelter, S., Feeney, B. and Thornton, C., Lost Lives: The Stories of the Men, Women and Children Who Died as a Result of the Northern Ireland Troubles (Edinburgh, 1999).

McNulty, T.A., Exiled: 40 Years an Exile (Monaghan, 2013).

McVeigh, J., Taking a Stand: Memoir of an Irish Parish Priest (Dublin, 2008).

Manseragh, M., The Legacy of History: For Making Peace in Ireland: Letters and Commemorative Addresses (Cork, 2003).

Meehan, C., A Just Society for Ireland? 1964-1987 (Hampshire, 2013).

Meehan, N., 'Eoghan Harris fed the hand that bit him', Village, Sept. 2009.

Meehan, N. and Murphy, B.P., The Embers of Revisionism: Essays Critiquing Creationist Irish History (Cork, 2017).

Merrigan, M., Eagle or Cuckoo? The Story of the ATGWU in Ireland (Dublin, 1989).

- Eggs and Rashers: Irish Socialist Memories (Dublin, 2014).

Mills, M., Hurler on the Ditch: Memoir of a Journalist who Became Ireland's First Ombundsman (Dublin, 2005).

Millward, S., Fast Forward: Music and Politics in 1974 (Leicester, 2016). 
Moore, C., The Christy Moore Songbook (Dingle, 1984).

Moran, J., Irish Birmingham: A History (Liverpool, 2010).

Morash, C., A History of the Media in Ireland (Cambridge, 2010).

Mullan, D., The Dublin and Monaghan Bombings (Dublin, 2000).

Mullen, M., Why Britain Should Leave Ireland (London, 1979).

Mullin, C., Error of Judgement: The Truth about the Birmingham Bombings (Dublin, 1997).

Mulroe, P., Bombs, Bullets and the Border: Policing Ireland's Frontier, Irish Security Policy, 1969-1978 (Dublin, 2017).

Murphy, C. and Adair, L., Untold Stories: Protestants in the Republic of Ireland 1922-2002 (Dublin, 2002).

Murphy, D., A Place Apart (London, 1978).

Murphy, J.A., Ireland in the Twentieth Century (Dublin, 1975).

- 'Further Reflections on Irish Nationalism', The Crane Bag 2, No. 1/2 (1978).

Murray Defence Campaign, No Hanging Here (Dublin, 1976).

Myers, K., Watching the Door: A Memoir, 1971-1978 (Dublin, 2006).

National Commemoration Committee, Tírghrá: Ireland's Patriot Dead (Dublin, 2002).

Noonan, J., What Do I Do Now? (Dublin, 2005).

Ó Beacháin, D., Destiny of the Soldiers: Fianna Fáil, Irish Republicanism and the IRA, 1926-1973 (Dublin, 2010).

O'Brien, C., Protecting Civil Liberties, Promoting Human Rights: 30 Years of the ICCL (Dublin, 2006).

O'Brien, C.C., States of Ireland (London, 1972).

- Herod: Reflections on Political Violence (London, 1978).

- Memoir: My life and themes (Dublin, 1998).

O'Brien, J., The Arms Trial (Dublin, 2000).

O'Brien, M., De Valera, Fianna Fáil and the Irish Press: The Truth in the News (Dublin, 2001).

- The Fourth Estate: Journalism in Twentieth Century Ireland (Manchester, 2017).

O'Brien, M. and Rafter, K. (Eds) Independent Newspapers: A History (Dublin, 2012).

O'Brien, M.C., The Same Age as the State: The Autobiography of Máire Cruise O'Brien (Dublin, 2003).

O'Callaghan, J., Teaching Irish Independence: History in Irish Schools, 1922-72 (Cambridge, 2009).

O'Callaghan, M., 'The Past Never Stands Still: Commemorating the Easter Rising in 1966 and 1976' in J. Smyth (Ed.) Remembering the Troubles (Notre Dame, 2017).

O'Callaghan, S. The Informer (London, 1999).

O'Connor, E., A Labour History of Waterford (Waterford, 1989).

- A Labour History of Ireland 1824-2000 (Dublin, 2011).

O'Connor, F., In Search of a State: Catholics in Northern Ireland (Belfast, 1993).

O'Connor Lysaght, R., End of a Liberal: the Literary Politics of Conor Cruise O'Brien (Dublin, 1976).

- (Ed.) 100 Years of Liberty Hall (Dublin, 2013).

Ó Corráin, D., Rendering to God and Caesar: The Irish Churches and the Two States in Ireland, 1949-73 (Manchester University Press, 2006).

O'Donnell, C., Fianna Fáil, Irish Republicanism and the Northern Ireland Troubles 1968-2005 (Dublin, 2007).

O'Donnell, R., Special Category: The IRA in English Prisons Vol.1: 1968-1978 (Dublin, 2012).

Ó Dúlaing, D., Donncha's World: The Roads, the Stories and the Wireless (Wexford, 2014).

Ó Faoleán, G., 'Ireland's Ho Chi Minh trail? The Republic of Ireland's role in the Provisional IRA's bombing campaign, 1970-1976', Small Wars \& Insurgencies 25 (October, 2014). 
O'Halloran, C., Partition and the Limits of Irish Nationalism (Dublin, 1987).

O'Halpin, E., Defending Ireland: The Irish State and its Enemies since 1922 (Oxford, 1999).

- 'A Greek Authoritarian Phase'? The Irish Army and the Irish Crisis, 1969-70', Irish Political Studies 23 (2008).

O'Hanlon, T.J., The Irish: Portrait of a People (London, 1975).

O'Leary, C., Irish Elections 1918-1977 (Dublin, 1979).

O'Leary, J., On the Doorsteps: Memoirs of a Long-serving TD (Kerry, 2015).

O'Leary, O., www.ewartbiggsprize.org.uk2013-2/olivia-olearys.

O'Mahony, A., Creating Space: The Education of a Broadcaster (Dublin, 2016).

O'Malley, D., Conduct Unbecoming (Dublin, 2014).

O Mally, P., The Uncivil Wars: Ireland Today (Boston, 1990).

O'Neill E. and Whyte, B.J., Two Little Boys: An Account of the Dublin \& Monaghan Bombings and their Aftermath (Dublin, 2004).

O'Neill. G., Where Were You? Dublin Youth Culture and Style 1950-2000 (Dublin, 2011).

Ó Riain, S., Provos: Patriots or Terrorists (Dublin, 1974).

O'Sullivan, M., Mary Robinson: The Life and Times of an Irish Liberal (Dublin, 1993).

O'Sullivan, P.M., Patriot Graves: Reistance in Ireland (Westchester, 1972).

Patterson, H., Ireland since 1939: The Persistance of Conflict (Dublin, 2007).

- Ireland's Violent Frontier: The Border and Anglo-Irish Relations During the Troubles (London, 2013).

- 'Unionism, 1921-1972' in A. Jackson (Ed.) The Oxford Handbook of Modern Irish History (Oxford, 2014).

Peck, J., Dublin From Downing Street (Dublin, 1978).

Penniman, H. (Ed.) Ireland at the Polls: The Dáil Elections of 1977 (Washington DC, 1978).

People's Democracy - Revolutionary Struggle, Fascism: The Threat in the North of Ireland (Dublin, 1975).

Perry, R., Revisionist Scholarship and Modern Irish Politics (Surrey, 2013).

Petit, P. (Ed.) The Gentle Revolution: The Crisis in Irish Universities (Dublin, 1969).

Pierse, M., Writing Dublin's working class: Dublin after O'Casey (London, 2011).

Pringle, P., About Time: Surviving Ireland's Death Row (Dublin, 2012).

Provisional IRA, Freedom Struggle (Dublin, 1973).

Puirséil, N., The Irish Labour Party, 1922-73 (Dublin, 2007).

Purcell, B., Inside RTE: A Memoir (Dublin, 2014).

Quinn, T. (Ed.) Desmond Fennell: His Life and Work (Dublin, 2002).

Rahaleen Ltd, All Over the Place: People Displaced to and from the Southern Border Counties as a Result of the Conflict 1969-1994 (Dublin, 2005).

Raven, J., Whelan, C.T., Pfretzschner, P.A. and Borock, D.M., Political Culture in Ireland: The Views of Two Generations (Dublin, 1976).

Regan, J.M., Myth and the Irish State (Dublin, 2013).

Revolutionary Struggle, Ireland: The Class War and Our Tasks (Dublin, 1977).

Reynolds, M., 'The Gaelic Athletic Association and the 1981 H-Block hunger strike', International Journal of the History of Sport 34 (June, 2017).

Rice, B., "'Hawks turn to Doves": the response of the post-revolutionary generation to the "new troubles" in Ireland, 1969-71', Irish Political Studies 30, No. 32 (2015).

Robinson, M., The Special Criminal Court (Dublin, 1974).

Ross, F.S., Smashing H-Block (Liverpool, 2011).

Rose, R., McAllister, I. and Mair, P., Is there a concurring majority about Northern Ireland?', Studies in Public Policy, No. 22 (Glasgow, 1978).

Sacks, P.M., The Donegal Mafia (Yale, 1976).

Savage, R., A Loss of Innocence: Television and Irish Society 1960-72 (Manchester, 2010).

Shaw, F., 'The canon of Irish history - a challenge', Studies 61 (Summer, 1972).

Sheehan, H., Irish Television Drama: a Society and its Stories (Dublin, 1987). 
Sheils-Makowski, B., Daughter of Derry: The Story of Brigid Sheils Makowski (London, 1989). Sheridan, E., Me Father was a Hero and me Mother is a Saint (Durham, 2011).

Sinn Féin the Workers Party, The Irish Industrial Revolution (Dublin, 1977).

Smith, R., Garret: The Enigma (Dublin, 1985).

Socialist Workers Movement, The Working Class and the National Question (Dublin, 1974).

Sorohan, S., Irish London during the Troubles (Dublin, 2012).

Sweeney, E., Down, Down, Deeper and Down: Ireland in the 70s and 80s (Dublin, 2010).

Sweetman, R., On Our Knees: Ireland, 1972 (London, 1972).

- On Our Backs: Sexual Attitudes in a Changing Ireland (London, 1979).

Thompson, E.P., The Making of the English Working Class (London, 1963).

Thornley, U., Unquiet Spirit: Essays in Memory of David Thornley (Dublin, 2008).

Tiernan, J., The Dublin and Monaghan Bombings (Dublin, 2004).

Tierney M. and MacCurtain, M., The Birth of Modern Ireland (Dublin, 1969).

Tobin, F., The Best of Decades: Ireland in the 1960s (Dublin, 1984).

Tóibín, C., Walking along the Border (London, 1987).

- 'New ways of killing your father', London Review of Books, 18 Nov. 1993.

Townshend, C. (Ed.) Consensus in Ireland: Approaches and Recessions (Oxford, 1988).

Travers, S. and Fetherstone, N., The Miami Showband Massacre: A Survivor's Search for Truth (Frontline Noir, 2017).

Uris, L. and Uris, J., Ireland: A Terrible Beauty: The Story of Ireland Today (New York, 1975).

Urwin, M., A State in Denial: British Collaboration with Loyalist Paramilitaries (Cork, 2016).

Vaughan, W.E. and Fitzpatrick, A.J., Irish Historical Statistics: Population, 1821-1971 (Dublin, 1978).

Viney, M., The Five Percent: A Survey of Protestants in the Irish Republic (Dublin, 1966).

Walsh, J., Patrick Hillery: The Official Biography (Dublin, 2008).

Walsh, L., The Final Beat: Gardai Killed in the Line of Duty (Dublin, 2001).

Walshe, E., Cissie's Abattoir (Cork, 2009).

Waters, J., Jiving at the Crossroads (Belfast, 1991).

Whelan, D., Who Stole Our Game? The Fall and Fall of Irish Soccer (Dublin, 2006).

Whitaker, A. (Ed.) Bright, Brilliant Days, Douglas Gageby and the Irish Times (Dublin, 2006).

White, J., Minority Report: The Protestants in the Republic of Ireland (Dublin, 1975).

White, J.T., Irish Devils: The Official Story of Manchester United and the Irish (London, 2012).

White, R.W., Ruairí Ó Brádaigh: The Life and Politics of an Irish Revolutionary (Indiana, 2006).

- Out of the Ashes: An Oral History of the Provisional Irish Republican Movement (Dublin, 2017).

Williamson, D.C., Anglo-Irish Relations in the Early Troubles: 1969-1972 (London, 2016).

Woods, P., 'Rumours from Monaghan: a radio documentary', The Irish Review (Spring, 2008).

\section{Official reports}

\section{Dáil Debates}

Houses of the Oireachtas, Interim Report on the Report of the Independent Commission of Inquiry into the Dublin and Monaaghan Bombings (Dublin, 2003).

Houses of the Oireachtas, Interim Report on the Report of the Independent Commission of Inquiry into the Dublin Bombings of 1972 and 1973 (Dublin, 2004).

Houses of the Oireachtas, Interim Report on the Report of the Independent Commission of Inquiry into the Bombing of Kay's Tavern, Dundalk (Dublin, 2006).

Irish Congress of Trade Unions, Annual Reports (Dublin, 1969-79). 


\section{Visual and audio sources}

Battle Station (RTE, 2011).

A Bloody Friday: the Dublin/Monaghan Bombings (TV3, 2010).

Bombings: Miami Showband (RTE, 2011).

Seven Ages (RTE, 2001).

Ireland: a Television History (BBC, 1980).

Cooke Street (RTE, 1977).

RTE Eadio 1: 'We Couldn't Understand the Peace' (2016).

RTE Radio 1: Rumours from Monaghan RTE (2008).

Green-and-blue.org.

\section{Theses and unpublished papers}

Finn, D., 'Challengers to Provisional Republicanism: The Official Republican Movement, People's Democracy and the Irish Republican Socialist Party, 1968-1998' (Phd: UCC, 2013).

Long, O., 'The Land that Made them Refugees: North-South Population Movements at the Outset of the Political Troubles, 1969-72' (MA: UCC, 2008).

Madden, G., 'Political Change in Northern Ireland and its Impact on the West of Ireland, 1968-1982' (MA: NUI Galway, 2013).

McGuill, P., 'Political Violence in the Republic of Ireland 1969-1997' (MA, UCD, 1998).

Mulroe, P., The Gardai, Violence and the Border: Irish Border Security policy 1969-1978 (PhD: UU, 2015).

Ní Bheachain, C., 'A Brief Examination/Analysis of the Intellectual Response to the DublinMonaghan Bombings of 1974' (Unpublished, N/D) Sean O'Mahony Papers, NLI. 